\title{
Regioselective Synthesis of 1,2,3-Triazoles Catalyzed Over ZnO Supported Copper Oxide Nanocatalyst as a New and Efficient Recyclable Catalyst in Water
}

\author{
Jalal Albadi, $^{1, *}$ Amir Alihosseinzadeh ${ }^{2}$ and Azam Mansournezhad ${ }^{1}$ \\ ${ }^{1}$ College of Science, Behbahan Khatam Alanbia University of Technology, Behbahan, Iran \\ ${ }^{2}$ School of Chemical Engineering, University of Tehran, Tehran, Iran \\ *Corresponding author: E-mail: Jalal.albadi@ gmail.com:Chemalbadi@ gmail.com \\ Tel/Fax: +986712229969
}

Received: 14-11-2014

\begin{abstract}
The $\mathrm{CuO} / \mathrm{ZnO}$ nanocatalysts are reported as efficient and recyclable catalysts for the regioselective synthesis of 1,2,3triazoles from benzyl halides and terminal alkynes in water. The catalysts are synthesized by a co-precipitation method and characterized by BET surface area, XRD, SEM, TEM and EDS analysis. The effect of CuO loading, catalyst amount and solvent was investigated. The catalyst can be recovered by a simple filtration and applied in consecutive runs with no loss of activity.
\end{abstract}

Keywords: $\mathrm{CuO} / \mathrm{ZnO}$ nanocatalyst, Sodium azide, 1,2,3-triazole, Click chemistry.

\section{Introduction}

Nowadays, synthesis of 1,2,3-triazoles has received considerable attention because of their wide range of applications. ${ }^{1} 1,2,3$-Triazoles are five-membered nitrogen heterocyclic compounds that have been broadly applied in various research fields including synthetic organic, medicinal, materials, and biological chemistry. ${ }^{2}$ These compounds are useful building blocks in the chemistry, resistant to moisture, oxygen, light, and also metabolism in the body. ${ }^{3}$ In addition, 1,2,3-triazoles are used as dyes, corrosion inhibition agents, photostabilizers, and photographic materials. ${ }^{4}$ The main method for the synthesis of 1,2,3-triazoles is the Huisgen 1,3-dipolar cycloaddition reaction of azides with alkynes. ${ }^{5}$ This reaction has been the model for click reactions which was introduced by Kolb and Sharpless in 2001. However, there are some catalytic reactions for the synthesis of 1,2,3-triazole derivatives. Copper-based catalysts can perform the cycloaddition reaction of azides with terminal alkynes by $\mathrm{Cu}(\mathrm{I})$ and/or $\mathrm{Cu}$ (II) species. ${ }^{6-21}$ Moreover, the performance of Ru-based catalysts on the cycloaddition of azides and terminal alkynes (RuAAC) for the regioselective synthesis of 1,2,3-triazoles has been reported. . $^{2-25}$

Recently, nanocatalysts have been extensively studied as competitive substitutes to the usual catalysts due

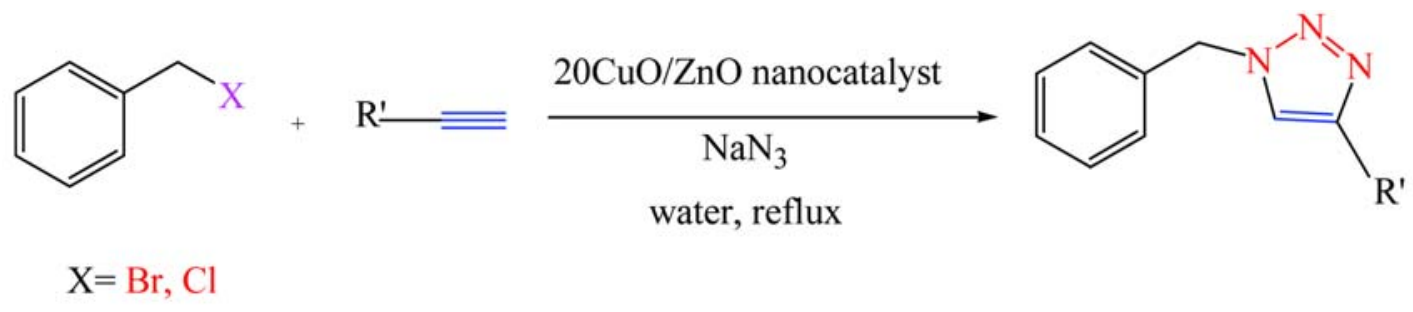

Scheme 1. Synthesis of 1,2,3-triazoles catalyzed by $20 \mathrm{CuO} / \mathrm{ZnO}$ nanocatalyst. 
to their comparable performance. ${ }^{26}$ Particularly, application of nano-metal oxides as catalysts in organic synthesis has been improved because of their significant characteristics. The recyclability of catalysts is an additional advantage of these catalysts. ${ }^{27}$

We have been putting our efforts towards the design and development of nanocatalysts. In our previous research, we have reported the activity of $\left(\mathrm{P}_{4} \mathrm{VPy}-\mathrm{CuI}\right), \mathrm{Cu}-$ $\mathrm{O}-\mathrm{CeO}_{2}$ and $\mathrm{Au}$ supported nanocatalysts as efficient recyclable nanocatalysts in organic synthesis. ${ }^{29-31}$ Moreover, as a part of our current research on the development of new routes to prepare heterocyclic systems, ${ }^{32-35}$ the performance of $\mathrm{CuO} / \mathrm{ZnO}$ nanocatalysts in the click synthesis of 1,2,3-triazoles from benzyl halides and terminal alkynes in water was investigated (Scheme 1).

\section{Results and Discussion}

The catalysts are synthesized by a co-precipitation method and characterized by BET surface area, XRD, SEM, TEM and EDS analysis. Figure 1, shows the XRD analysis of $\mathrm{ZnO}$ and $20 \mathrm{CuO} / \mathrm{ZnO}$ samples.

There are several peaks attributed to $\mathrm{ZnO}$ at a wide range of $2 \theta=31.7,34.3,36.3,47.3,56.4,62.8,66.2,67.8$, 69.0, 72.5 and 76.9 degrees which are characteristics of (100), (002), (101), (102), (110), (103), (200), (112),

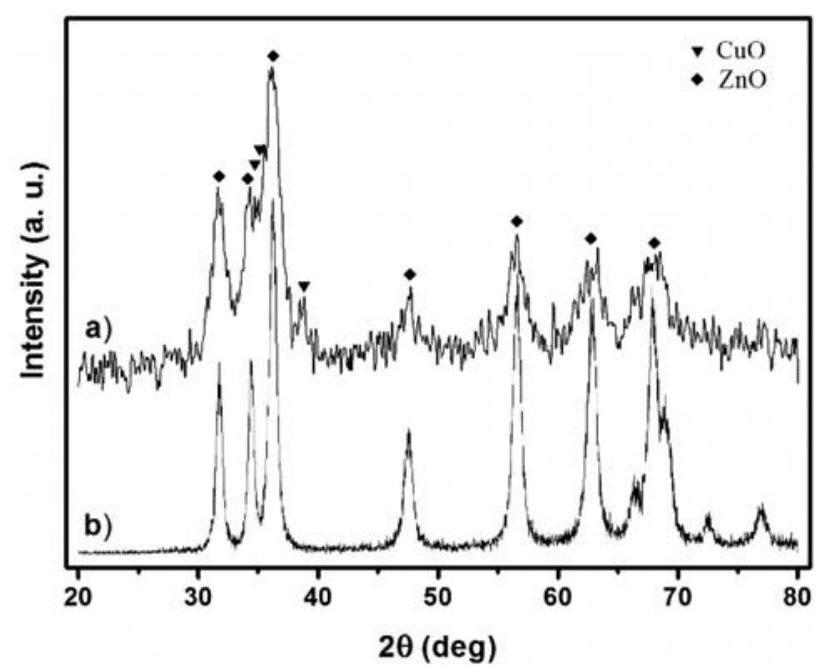

Figure 1. $\mathrm{XRD}$ patterns of (a) $\mathrm{ZnO}$, and (b) $20 \mathrm{CuO} / \mathrm{ZnO}$ nanocatalyst.
(201), (004) and (202) planes based on JCPDS card No. 89-1397. For the $20 \mathrm{CuO} / \mathrm{ZnO}$ catalyst, the diffraction peaks at $35.5,35.6,38.7$ and $38.92^{\circ}$, are attributed to (002), (111) , (111) and (200) planes of cubic $\mathrm{CuO}$, respectively (cod No. 05-0661). The peaks for $\mathrm{ZnO}$ crystals in $20 \mathrm{CuO} / \mathrm{ZnO}$ have lower intensity and are broadened after addition of $\mathrm{CuO}$ to the $\mathrm{ZnO}$. That indicates a lower crystallinity and smaller crystallite sizes of $\mathrm{ZnO}$ crystallites, maybe due to the incorporation of $\mathrm{CuO}$ in to the structure of $\mathrm{ZnO}$. As shown in Table 1, the $\mathrm{ZnO}$ crystallite size is about 23 and $12 \mathrm{~nm}$ for $\mathrm{ZnO}$ support and $20 \mathrm{CuO} / \mathrm{ZnO}$ catalyst, respectively. Also, the average crystallite size of $\mathrm{CuO}$ in the catalyst is about $8 \mathrm{~nm}$. The structural properties of prepared samples are presented in Table 1.

The BET surface area of $\mathrm{ZnO}$ support is $53 \mathrm{~m}^{2} / \mathrm{g}$, and as $20 \mathrm{wt} \% \mathrm{CuO}$ is loaded on the support, the surface area increases to $89 \mathrm{~m}^{2} / \mathrm{g}$. As shown in Table 1, after $\mathrm{CuO}$ loading on $\mathrm{ZnO}$ the pore volume of $20 \mathrm{CuO} / \mathrm{ZnO}$ increases, while its pore size decreases, simultaneously. The $\mathrm{N}_{2}$ adsorption/desorption profiles for $\mathrm{ZnO}$ and $20 \mathrm{CuO} / \mathrm{ZnO}$ samples are shown in Figure 2a. According to the IUPAC classification, these isotherms can be categorized as type IV at the borderline with type II, with a type H3 hysteresis loop. This isotherm indicates the presence of mesopores with a pore size distribution continuing into the macropore domain ${ }^{36}$ (Figure $2 b$ ). In addition, the type $\mathrm{H} 3$ hysteresis is usually observed on solids containing aggregates or agglomerates of some particles leading to slit-shaped pores, with nonuniform size and/or shape. Furthermore, the reflection point on $\mathrm{ZnO}$ occurs at around $P / P^{0}=0.86$, and by an increase of $\mathrm{CuO}$ it shifts to a lower value of around 0.8 for $20 \mathrm{CuO} / \mathrm{ZnO}$. These results suggested the smaller mesopores in the samples containing $\mathrm{Cu}$ content. Furthermore, higher amounts of $\mathrm{N}_{2}$-adsorption on $20 \mathrm{CuO} / \mathrm{ZnO}$ nanocatalyst can be related to mesopores with higher pore volume. These results are consistent with the average pore size and pore volume of the samples shown in Table 1.

Figure 3 shows the SEM analysis of $\mathrm{ZnO}$ and $20 \mathrm{Cu}$ $\mathrm{O} / \mathrm{ZnO}$.

The $\mathrm{ZnO}$ micrograph (Figure 3a) exhibits an aggregation of nano-slit-like particles. However, the morphology of the catalyst after $\mathrm{Cu}$ loading is changed drastically. As can be seen, incorporation of $\mathrm{Cu}$ into the $\mathrm{ZnO}$ has a significant effect on the morphology of the catalyst. The $20 \mathrm{CuO} / \mathrm{ZnO}$ sample exhibits an agglomerate of nanoparticles with a particle size of about $38 \mathrm{~nm}$ in diameter.

Table 1: Structural properties of prepared samples.

\begin{tabular}{|c|c|c|c|c|c|}
\hline \multirow[t]{2}{*}{ 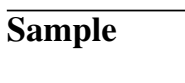 } & \multicolumn{2}{|c|}{ Crystallite Size $^{\mathrm{a}}(\mathrm{nm})$} & \multirow{2}{*}{$\begin{array}{c}S_{\text {BET }} \\
\left(\mathbf{m}^{2} / \mathbf{g}\right)\end{array}$} & \multirow{2}{*}{$\begin{array}{l}\text { Pore volume } \\
\left(\mathrm{cm}^{3} / \mathrm{g}\right)\end{array}$} & \multirow{2}{*}{$\begin{array}{c}\text { Pore Size } \\
(\mathbf{n m})\end{array}$} \\
\hline & $D_{\mathrm{CuO}}$ & $D_{\mathrm{ZnO}}$ & & & \\
\hline$\overline{\mathrm{ZnO}}$ & - & 23 & 53 & 0.13 & 22.6 \\
\hline $20 \mathrm{CuO} / \mathrm{ZnO}$ & 8 & 12 & 89 & 0.32 & 17.9 \\
\hline
\end{tabular}

${ }^{a}$ Average $\mathrm{CuO}$ crystal size calculated by XRD. 

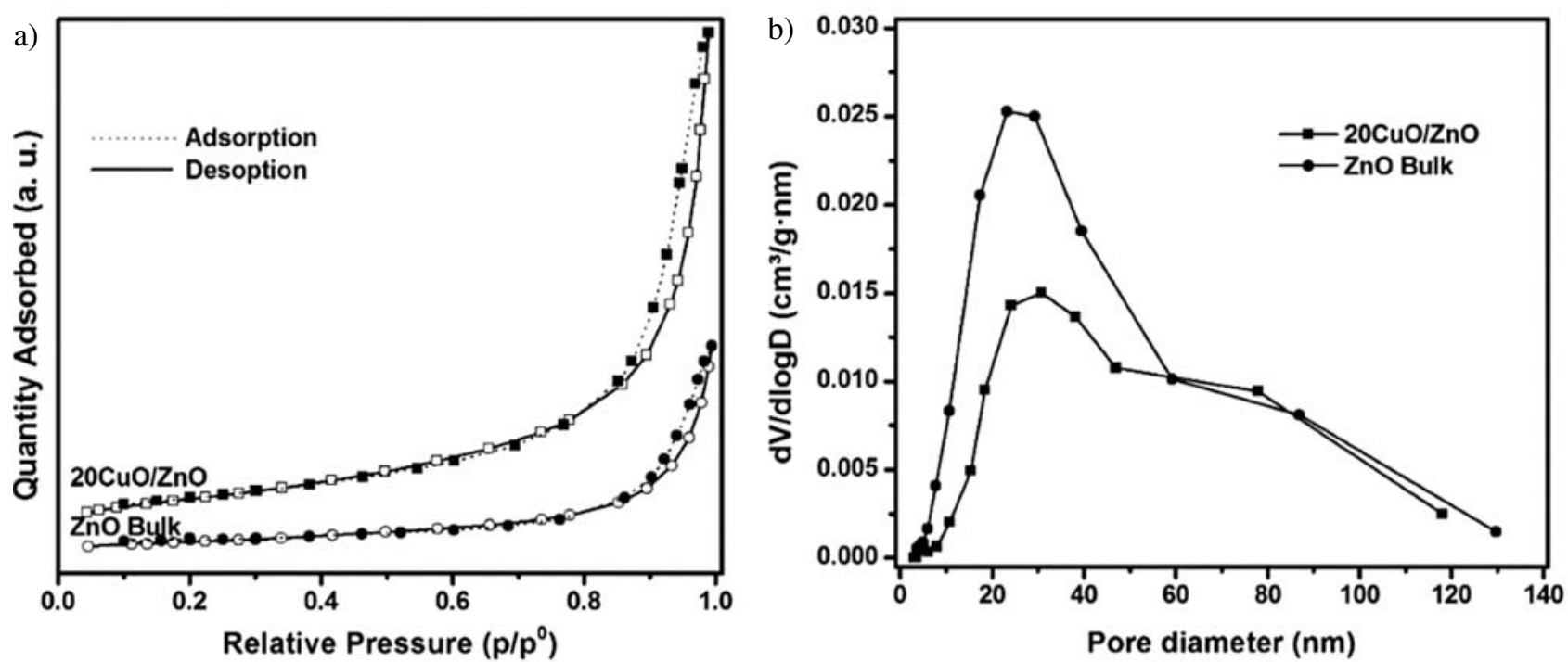

Figure 2. (a) $\mathrm{N}_{2}$ adsorption/desorption isotherms, and (b) pore size distributions, of $\mathrm{ZnO}$ and $20 \mathrm{CuO} / \mathrm{ZnO}$ samples.
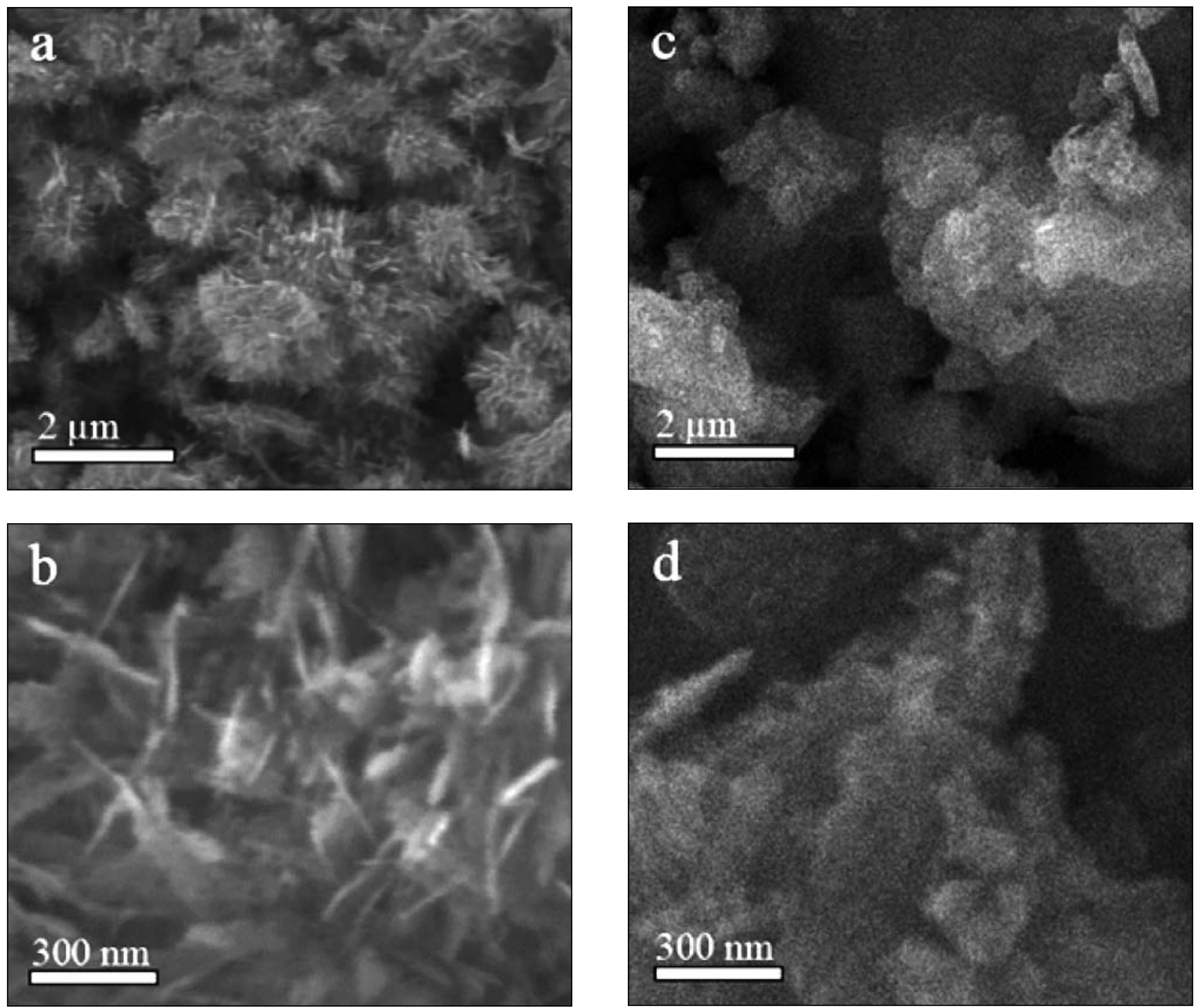

Figure 3. SEM micrographs of (a,b) $\mathrm{ZnO}$, and (c,d) $20 \mathrm{CuO} / \mathrm{ZnO}$ samples. 
Figure 4a shows TEM image and $\mathrm{CuO}$ particle size distribution of $20 \mathrm{CuO} / \mathrm{ZnO} . \mathrm{CuO}$ nanoparticles are highly

Table 2. Effect of $\mathrm{CuO}$ loading on the yield of 1,2,3-triazoles. ${ }^{\mathrm{a}}$

\begin{tabular}{ccccc}
\hline Entry & $\begin{array}{c}\text { CuO loading } \\
\text { (wt. \%) }\end{array}$ & $\begin{array}{c}\text { Catalyst mass } \\
(\mathbf{g})\end{array}$ & $\begin{array}{c}\text { Time } \\
(\mathbf{m i n})\end{array}$ & $\begin{array}{c}\text { Yield } \\
(\boldsymbol{\%})\end{array}$ \\
\hline 1 & 5 & 0.05 & 180 & Trace \\
2 & 5 & 0.07 & 180 & 5 \\
3 & 5 & 0.1 & 180 & 10 \\
4 & 10 & 0.05 & 180 & 20 \\
5 & 10 & 0.07 & 180 & 30 \\
6 & 10 & 0.1 & 180 & 35 \\
7 & 20 & 0.05 & 60 & 80 \\
8 & 20 & 0.07 & 20 & 92 \\
\hline
\end{tabular}

${ }^{a}$ Reaction conditions: benzyl bromide $(1 \mathrm{mmol})$, phenylacetylene $(1 \mathrm{mmol})$, sodium azide $(1.1 \mathrm{mmol})$ in water at reflux conditions. ${ }^{\mathrm{b}}$ Isolated pure products.
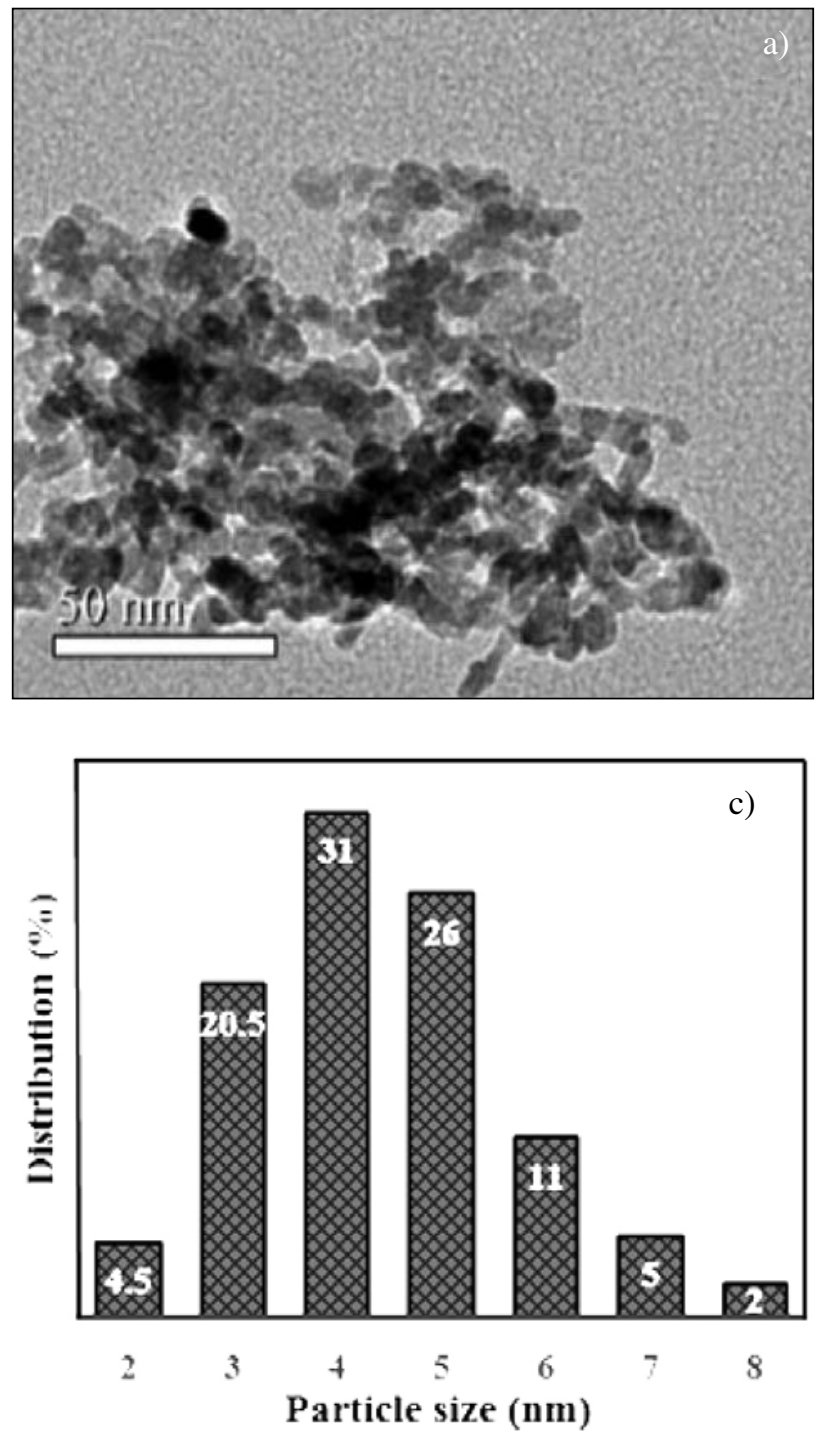

dispersed on the catalyst surface. Figure 4a-inset picture exhibits the $\mathrm{CuO}$ nanoparticle size distribution, by an average $\mathrm{CuO}$ particle size of about $4.4 \mathrm{~nm}$. The HRTEM ima-

Table 3. Optimization of the reaction conditions.

\begin{tabular}{lcccc}
\hline Entry & Conditions $^{\mathbf{a}}$ & $\begin{array}{c}\text { Catalyst } \\
\text { mass }(\mathbf{g})\end{array}$ & $\begin{array}{c}\text { Time } \\
(\mathbf{m i n})\end{array}$ & $\begin{array}{c}\text { Yield } \\
\mathbf{\%})^{\mathbf{b}}\end{array}$ \\
\hline 1 & $\mathrm{H}_{2} \mathrm{O}$ & - & 120 & - \\
2 & $\mathrm{H}_{2} \mathrm{O}$ & 0.05 & 60 & 80 \\
3 & $\mathrm{H}_{2} \mathrm{O}$ & 0.07 & 20 & 92 \\
4 & $\mathrm{CH}_{3} \mathrm{CH}_{2} \mathrm{OH}$ & - & 120 & - \\
5 & $\mathrm{CH}_{3} \mathrm{CH}_{2} \mathrm{OH}$ & 0.05 & 90 & 50 \\
6 & $\mathrm{CH}_{3} \mathrm{CH}_{2} \mathrm{OH}$ & 0.07 & 60 & 75 \\
7 & $\mathrm{CH}_{3} \mathrm{OH}$ & 0.07 & 90 & 75 \\
8 & $\mathrm{CH}_{2} \mathrm{Cl}$ & 0.07 & 120 & Trace \\
9 & $\mathrm{CH}_{3} \mathrm{CN}$ & 0.07 & 120 & Trace \\
\hline
\end{tabular}

${ }^{\mathrm{a}}$ Reflux conditions. ${ }^{\mathrm{b}}$ Isolated pure products.
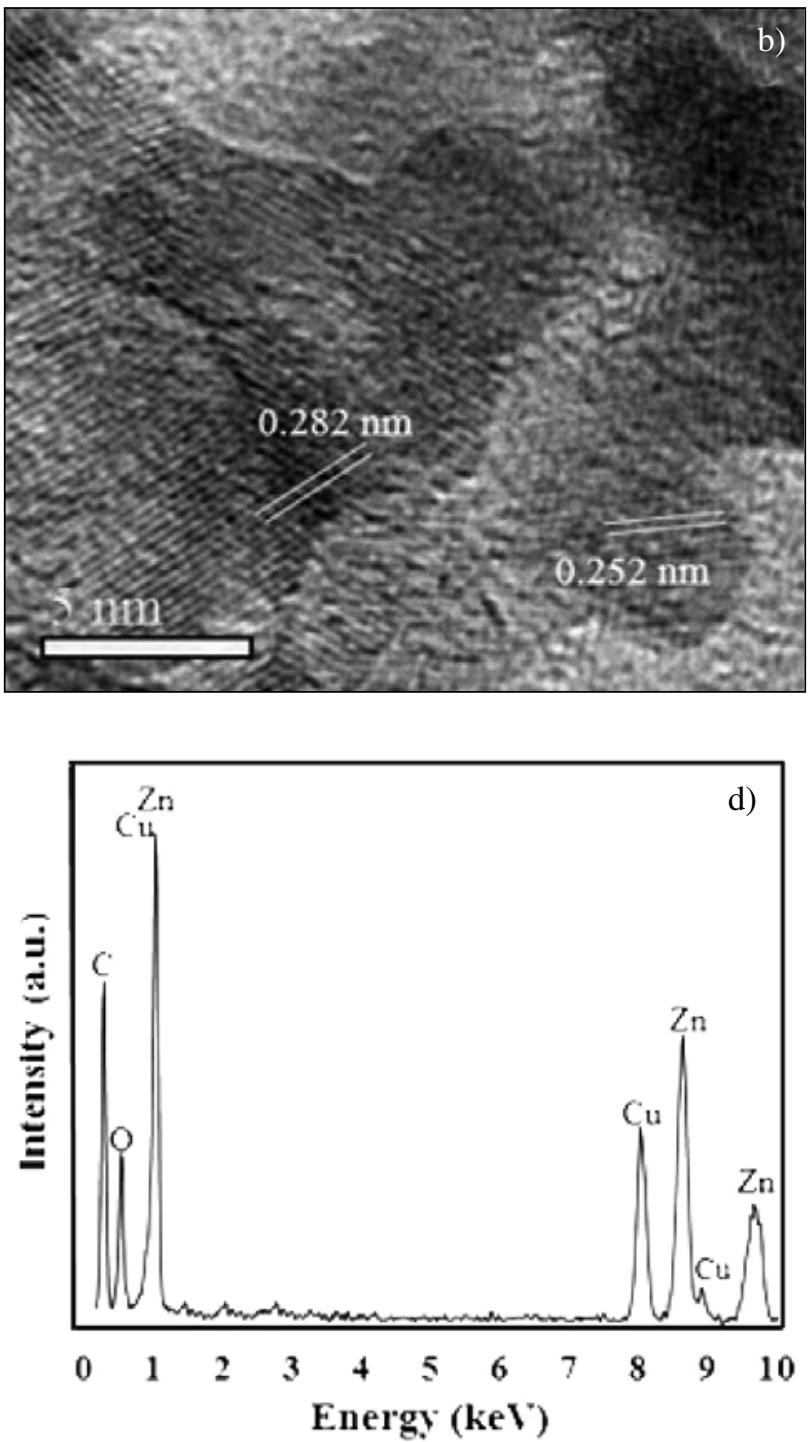

Figure 4. (a,b) TEM image, (c) particle size distribution, and (d) EDS analysis, of 20CuO-ZnO nanocatalyst. 
Table 4. Synthesis of 1,2,3- triazoles catalyzed by $20 \mathrm{CuO} / \mathrm{ZnO}$.

\begin{tabular}{|c|c|c|c|c|c|}
\hline Entry & Substrate & Alkyne & Time (min) & Yield $(\%)^{\text {a }}$ & m.p. $\left({ }^{\circ} \mathbf{C}\right)^{\mathrm{b}}$ \\
\hline 1 & & & 20 & 92 & $128-130$ \\
\hline 2 & & & 20 & 91 & 109-111 \\
\hline 3 & & & 15 & 92 & $117-119$ \\
\hline 4 & & & 35 & 90 & $148-149$ \\
\hline 5 & & & 35 & 91 & $140-141$ \\
\hline 6 & & & 30 & 89 & 136-137 \\
\hline 7 & & & 20 & 90 & 139-141 \\
\hline 8 & & & 45 & 89 & 188-190 \\
\hline 9 & & & 30 & 92 & $127-129$ \\
\hline 10 & & & & & \\
\hline 11 & & & 18 & 89 & $117-119$ \\
\hline 12 & & & 60 & 91 & $148-150$ \\
\hline 13 & & & $\begin{array}{l}65 \\
35\end{array}$ & $\begin{array}{l}90 \\
89\end{array}$ & $\begin{array}{c}188-190 \\
77-79\end{array}$ \\
\hline 14 & & & 45 & 89 & $77-79$ \\
\hline
\end{tabular}

${ }^{\mathrm{a}}$ Ioslated pure products. ${ }^{\mathrm{b}}$ Products were characterized by comparison of their spectroscopic data and melting points with those reported in the literature. ${ }^{19,35}$

ge of $20 \mathrm{CuO} / \mathrm{ZnO}$ is shown in Figure $4 \mathrm{~b}$. The reflections with $d$-spacing values of 0.282 and $0.252 \mathrm{~nm}$ correspond to $\mathrm{ZnO}(100)$ and $\mathrm{CuO}(11 \overline{1})$ lattice planes.

For the optimization of reaction conditions, various parameters such as $\mathrm{CuO}$ loading, catalyst amount and solvent were investigated. Initially, the reaction between ben- zyl bromide, phenylacetylene and sodium azide, in the presence of the catalyst as a model reaction was investigated (Scheme 1). The perofrmance of various $\mathrm{CuO} / \mathrm{ZnO}$ nanocatalysts containing 5, 10 and $20 \mathrm{wt} . \% \mathrm{CuO}$ in the synthesis of 1,2,3-triazoles were investigated. As shown in Table 2, with an increase of $\mathrm{CuO}$ content, the activity of 
the catalysts increases, and the $20 \mathrm{CuO} / \mathrm{ZnO}$ showed the highest yield of reaction (about 92\%), in a relatively short reaction time $(20 \mathrm{~min})$. Also, in the presence of $\mathrm{ZnO}$ blank and CuO-bulk no produsts were obtained. These results demonstrated the effect of $\mathrm{CuO}$ nanoparticles on the synthesis of 1,2,3-triazoles. Also, it should be noted that no product was obtained in the absence of the catalyst (blank test) under these reaction condition.

Table 3 shows that the best results was achieved by the reaction of benzyl bromide, phenylacetylene and sodium azide (1: $1: 1.1 \mathrm{~mol} / \mathrm{ratio})$ in the presence of $0.07 \mathrm{~g}$ of the catalyst in water as the solvent under reflux condition (Table 3). The other solvents such as ethanol, methanol, $\mathrm{CH}_{3} \mathrm{CN}$, and $\mathrm{CH}_{2} \mathrm{Cl}_{2}$ resulted in lower yields.

The activity of various terminal alkynes and benzyl halides under optimized conditions is summarized in Table 4. It is clear that a substitution with electron withdrawing or electron donating groups on the phenyl rings did not have a significant effect on the result of the reaction. It should be noted that the corresponding triazoles were obtained with high yields and regioselectivities. Moreover, the obtained products can be isolated by a simple filtration and recrystallized from a mixture of ethanol/water $(3: 1 \mathrm{v} / \mathrm{v})$.

Furthermore, the recyclability of the catalyst for the reaction of benzyl bromide and phenylacetylene under optimized conditions was investigated. After completion of each reaction, the spent catalyst was recovered by filtration. Then it was washed with hot ethanol, dried and used for the next run. The recovered catalyst showed a sustained performance after 5 consecutive runs with no loss of activity. Also, the results demonstrated high selectivity and high yields of corresponding products in the five consecutive runs (Table 5).

Table 5. Recyclability study of $20 \mathrm{CuO} / \mathrm{ZnO}$ nanocatalyst.

\begin{tabular}{lccccc}
\hline Run & 1 & 2 & 3 & 4 & 5 \\
Time (min) & 20 & 22 & 22 & 25 & 32 \\
Yield $(\%)^{\mathrm{a}}$ & 92 & 92 & 91 & 90 & 88 \\
\hline
\end{tabular}

${ }^{\mathrm{a}}$ Ioslated pure products.

\section{Experimental}

Chemicals were purchased from Merck. Products were characterized by comparison of their spectroscopic data ( ${ }^{1} \mathrm{H}$ NMR, ${ }^{13} \mathrm{C}$ NMR and IR) and physical properties with those reported in the literature. NMR spectra were recorded in DMSO- $d_{6}$ or $\mathrm{CDCl}_{3}$ on a Bruker Avance DPX 500 and $400 \mathrm{MHz}$ spectrometers. IR spectra were recorded on a BOMEMMB-Series 1998 FT-IR spectrometer. All yields refer to isolated products. The Bruker AXS D8 advanced diffractometer carried out the XRD analysis of the catalyst. The sample was scanned over the range of
$2 \theta=10-80^{\circ}$ using $\mathrm{Cu}$ Ká radiation. The specific surface area of samples was determined by nitrogen adsorptiondesorption using BET method, using an automated gas adsorption analyzer (Tristar 3020, Micromeritics). The morphology of the catalyst was investigated comprehensively by scanning electron microscopy (SEM) and high resolution transmission electron microscopy (HRTEM) techniques using a HITACHI S-4160 instrument, as well as JEOL JEM-2100 $(200 \mathrm{kV})$ microscope equipped with an EDS analytical system.

\section{1. Preparation of the Catalyst}

The $\mathrm{CuO} / \mathrm{ZnO}$ catalysts containing 5 to $20 \mathrm{wt}$. $\%$ $\mathrm{CuO}$, were prepared by co-precipitation method. A $\mathrm{Na}_{2} \mathrm{CO}_{3} \mathrm{H}_{2} \mathrm{O}$ solution was added drop-wise into an approperiate mixture of $0.03 \mathrm{M} \mathrm{Cu}\left(\mathrm{NO}_{3}\right)_{2} 3 \mathrm{H}_{2} \mathrm{O}$ and $\mathrm{Zn}\left(\mathrm{NO}_{3}\right)_{3} 6 \mathrm{H}_{2} \mathrm{O}$ solutions under continuous mixing. The slurry was kept at $\mathrm{pH} 8.5$ for $15 \mathrm{~min}$ at $65^{\circ} \mathrm{C}$, then filtered and washed with deionized water. The precipitates were dried for $12 \mathrm{~h}$ at $100{ }^{\circ} \mathrm{C}$ followed by calcination at $300{ }^{\circ} \mathrm{C}$ for $3 \mathrm{~h}$. The final catalyst is denoted as $x \mathrm{CuO} / \mathrm{Zn}$ $\mathrm{O}$ where $x$ is the weight percent of the copper oxide in the catalyst.

\section{2. General Procedure}

A mixture of benzyl halide ( $1 \mathrm{mmol})$, terminal alkyne $(1 \mathrm{mmol})$, sodium azide $(1.1 \mathrm{mmol})$, and proper amount of the catalyst was stirred in water under reflux condition for the appropriate time (Table 3 ). After reaction completion, the mixture was cooled, filtered and added to hot ethanol. The filtrate was evaporated and dried. Then, the obtained solid was recovered in a hot ethanol/water $(3: 1 \mathrm{v} / \mathrm{v})$ and the catalyst was washed with hot ethanol, dried and applied for consecutive runs.

\section{Conclusion}

In this research $\mathrm{CuO} / \mathrm{ZnO}$ nanocatalysts as efficient recyclable catalysts were introduced for the click synthesis of 1,2,3-triazoles under reflux conditions in water. The catalysts demonstrated a satisfactory yield of about $88 \%$ after 5 consecutive runs, with sustained activity. Clean procedure, easy work-up, short reaction time and high yields of corresponding products make this method an attractive procedure for the synthesis of 1,2,3-triazoles.

\section{Acknowledgement}

We are thankful to research council of Behbahan Khatam Alanbia University of Technology for the support of this work. 


\section{References}

1. D. R. Buckle, D. J. Outred, C. J. M. Rockell, H. Smith, B. A. Spicer, J. Med. Chem. 1983, 26, 251-254. http://dx.doi.org/10.1021/jm00356a025

2. Y. Xia, Z. Fan, J. Yao, Q. Liao, W. Li, F. Qu, L. Peng, Bioorg. Med. Chem. Lett. 2006, 16, 2693-2698. http://dx.doi.org/10.1016/j.bmcl.2006.02.023

3. D. Kumar, V. Buchi Reddy, R. S. Varma, Tetrahedron Lett. 2009, 50, 2065-2068. http://dx.doi.org/10.1016/j.tetlet.2009.02.107

4. T. Lee, M. Cho, S. Y. Ko, H. J. Youn, D. J. Baek, W. J. Cho, C.Y. Kang, S. J. Kim, J. Med. Chem. 2007, 50, 587-589.

5. R. Huisgen, Pure Appl. Chem. 1989, 61, 613-628. http://dx.doi.org/10.1351/pac198961040613

6. I. S. Park, M. S. Kwon, Y. Kim, J. S. Lee, J. Park, Org. Lett. 2008, 10, 497-500. http://dx.doi.org/10.1021/ol702790w

7. B. S. Lee, M. Yi, S. Y. Chu, J. Y. Lee, H. R. Kwon, K. R. Lee, D. Kang, W. S. Kim, H. B. Lim, J. Lee, H.-J. Youn, D. Y. Chi, N. H. Hur, Chem. Commun. 2010, 46, 3935-3937. http://dx.doi.org/10.1039/c001255f

8. M. Laksmi Kantam, V. Swarna Jaya, B. Sreedhar, M. Mohan Rao, B. M. Choudary, J. Mol. Catal. A: Chem. 2006, 256, 273-277. http://dx.doi.org/10.1016/j.molcata.2006.04.054

9. F. Alonso, Y. Moglie, G. Radivoy, M. Yus, Adv. Synth. Catal. 2010, 352, 3208-3214.

http://dx.doi.org/10.1002/adsc.201000637

10. H. Sharghi, R. Khalifeh, M. M, Doroodmand, Adv. Synth. Catal. 2009, 351, 207-218. http://dx.doi.org/10.1002/adsc.200800612

11. D. Wang, N. Li, M. Zhao, W. Shi, C. Ma, B. Chen, Green. Chem. 2010, 12, 2120-2123. http://dx.doi.org/10.1039/c0gc00381f

12. L. V. Lee, L. Michaell, S. J Huang, V. V. Fokin, K. B. Sharpless, C. H. Wong, J. Am. Chem. Soc. 2003, 125, 9588-9589. http://dx.doi.org/10.1021/ja0302836

13. P. Appukkuttan, W. Dehaen, V. V. Fokin, V. Eycken, Org. Lett. 2004, 6, 4223-4225. http://dx.doi.org/10.1021/ol048341v

14. J. Y. Kim, J. C. Park, H. Kang, H. Song, K. H. Park, Chem. Commun. 2010, 46, 439-441. http://dx.doi.org/10.1039/B917781G

15. S. Mohammad, A. K. Padala, B. A. Dar, B. Singh, B. Sreedhar, R. A. Vishwakarma, S. B. Bharate, Tetrahedron 2012, 68, 8156-8162. http://dx.doi.org/10.1016/j.tet.2012.07.080

16. N. W. Smith, B. P. Polenz, S. B. Johnson, S. V. Dzyuba, Tetrahedron Lett. 2010, 51, 550-553. http://dx.doi.org/10.1016/j.tetlet.2009.11.089

17. J. C. Park, A. Y. Kim, J. Y. Kim, S. Park, K. H. Park, H. Song, Chem. Comm. 2012, 48, 8484-8486.

http://dx.doi.org/10.1039/c2cc31654d
18. S. Roy, T. Chatterjee, M. Pramanik, A. Singha Roy, A. Bhaumik, S. Manirul Islam, J. Mol. Catal. A: Chem. 2014, 386, 78-85. http://dx.doi.org/10.1016/j.molcata.2014.01.027

19. T. Shamim, S. Paul, Catal. Lett. 2010, 136, 260-265. http://dx.doi.org/10.1007/s10562-010-0330-3

20. L. Wan, C. Cai, Catal. Lett. 2012, 142, 1134-1140. http://dx.doi.org/10.1007/s10562-012-0880-7

21. S. C. Radatz, L. D. Amarai Soarez, E. R. Vieira, D. Alves, D. Russowsky, P. H. Schneider, New J. Chem. 2014, 38, 14101417. http://dx.doi.org/10.1039/c3nj01167d

22. S. Oppilliart, G. Mousseau, L. Zhang, G. Jia, P. Thuery, B. Rousseau and J. C. Cintrat, Tetrahedron 2007, 63, 80948098. http://dx.doi.org/10.1016/j.tet.2007.06.008

23. D. R. Hou, T. C. Kuan, Y. K. Li, R. Lee, K. W. Huang, Tetrahedron 2010, 66, 9415-9420.

http://dx.doi.org/10.1016/j.tet.2010.09.099

24. P. N. Liu, H. X. Siyang, L. Zhang, S. K. S. Tse, G. Jia, J. Org. Chem. 2012, 77, 5844-5849.

http://dx.doi.org/10.1021/jo3008572

25. P. N. Liu, J. Li, F. H. Su, K. D. Ju, L. Zhang, C. Shi, H. H. Y. Sung, I. D. Williams, V. V. Fokin, Z. Lin, G. Jia, Organometallics 2012, 31, 4904-4915. http://dx.doi.org/10.1021/om300513w

26. T. M. Trnka, R. H. Grubbs, Acc. Chem. Res. 2000, 34, 18- 29. http://dx.doi.org/10.1021/ar000114f

27. S. M. Agawane, J. M. Nagarkar, Tetrahedron Lett. 2011, 52, 5220-5223. http://dx.doi.org/10.1016/j.tetlet.2011.07.117

28. J. Albadi, A. Alihoseinzadeh, A. Razeghi, Catal. Commun. 2014, 49, 1-5.

http://dx.doi.org/10.1016/j.catcom.2014.01.030

29. J. Albadi, J. Abbasi Shiran, A. Mansournezhad, Acta. Chim. Slov. 2014, 61, 900-903.

30. J. Albadi, A. Mansournezhad, H. Abbaszadeh, J. Chin. Chem. Soc. 2013, 60, 1193-1196.

31. J. Albadi, A. Mansournezhad, Z. Derakhshandeh, Chin. Chem. Lett. 2013, 24, 821-824.

http://dx.doi.org/10.1016/j.cclet.2013.05.031

32. J. Albadi, A. Mansournezhad, F. Akbari Balout- Bangan, Acta. Chim. Slov. 2014, 61, 185-190.

33. J. Albadi, M. Keshavarz, F. Shirini, M. Vafaie-nezhad, Catal. Commun. 2012, 27, 17-20.

http://dx.doi.org/10.1016/j.catcom.2012.05.023

34. J. Albadi, M. Keshavarz, Synth. Commun. 2013, 43, 20192030. http://dx.doi.org/10.1080/00397911.2012.671434

35. J. Albadi, J. Abbasi Shiran, A. Mansournezhad, J. Chem. Sci. 2014, 126, 147-150. http://dx.doi.org/10.1007/s12039-013-0537-0

36. R. A. Sheldon. Catal. Today. 1987, 1, 351-355. http://dx.doi.org/10.1016/0920-5861(87)80017-2 


\section{Povzetek}

Poročamo o $\mathrm{CuO} / \mathrm{ZnO}$ nanokatalizatorjih kot učinkovitih katalizatorjih za regioselektivno sintezo 1,2,3-triazolov iz benzil halidov in terminalnih alkinov v vodi. Ti katalizatorji so zelo učinkoviti poleg tega pa jih je mogoče tudi enostavno reciklirati. Pripravili smo jih z metodo so-obarjanja ter karakterizirali z določevanjem površine z BET metodo ter z XRD, SEM, TEM in EDS analizami. Raziskali smo učinek deleža CuO v katalizatorju, mase katalizatorja in lastnosti uporabljenega topila. Pokazali smo, da lahko katalizatorje recikliramo z enostavno filtracijo in uporabimo v ponovljenih reakcijah brez zmanjšane aktivnosti. 